\title{
Protein and Lipid Content of Microalgae Scenedesmus sp. Biomass Grown in Wet Market Wastewater
}

\author{
Najeeha Mohd Apandi ${ }^{1}$, Radin Maya Saphira Radin Mohamed ${ }^{1,}{ }^{*}$, Nur Atikah Ahmad \\ Latiffi $^{l}$, Nur Farahanim Mohd Rozlan ${ }^{l}$, and A.A.S. Al-Gheethi ${ }^{l}$ \\ ${ }^{1}$ Department of Water and Environmental Engineering, Faculty of Civil and Environmental \\ Engineering, Universiti Tun Hussein Onn Malaysia, 86400 Parit Raja, Batu Pahat, Johor, Malaysia
}

\begin{abstract}
Microalgae biomass is a type of organism that has various advantages and often used for variety of uses not only for wastewater treatment purposes but also serve as bio-based products development. Because of high in protein and lipid accumulation, this freshwater microalgae Scenedesmus sp. was selected for the present study. In this study, microalgae Scenedesmus sp. was grown in four concentrations of wet market wastewater $(10 \% \mathrm{WM}, 15 \% \mathrm{WM}, 20 \% \mathrm{WM}$ and $25 \% \mathrm{WM})$ in comparison with the Bold Basal Medium (BBM) as a control. The result shows that the highest protein content $(50.72 \%)$ was in $10 \% \mathrm{WM}$ followed by $15 \% \mathrm{WM}, 20 \% \mathrm{WM}, 25 \% \mathrm{WM}$ and BBM. As for lipid content, the best concentration was obtained in the $25 \% \mathrm{WM}$ with the value of $26.7 \%$ compared to other concentrations and BBM. Therefore, the result indicates that microalgae Scenedesmus sp. biomass cultured using wet market wastewater has a great potential in producing protein-rich and lipid content which significantly could be used as a fish feed product.
\end{abstract}

\section{Introduction}

An assortment of microalgae, including Scenedesmus sp. have been concentrated on for their conceivable viability as bioresources for application as fish feed, supplement, human consumption due to their nutritious compounds eg; protein, lipids, carbohydrates and other valuable trace element and additionally for the bioremediation of contaminated water [1-3]. In recent years, many researchers have studied the value potential of dual application of microalgae for wastewater treatment and biomass production [4, 5]. Unfortunately, wastewater from wet market contain nutrient and elements derived from the fresh foodstuff, waste scraps of poultry and fish entrails which consists of variety components such as nitrogen and phosphorus commonly discharge directly to the drainage without any treatment [6]. In Malaysia, the disposal of these wastewaters is commonly direct into the drainage and end up flowing into the river. This phenomenon escalates the pollution to obnoxious smell and filthy surrounding environment due to the wastewater discharge

* Corresponding author: maya@uthm.edu.my 
freely. This issue may prompt an uncomfortable condition directly to the people and occupants at the wet market business area [7].

Basically, conventional wastewater treatment is highly expensive due to chemicals needed to treat the wastewater. However, biological treatment using microalgae as an alternative to reduce the pollutant with less expensive and at the same time valuable biomass microalgae can be produced. Microalgae based wastewater treatment is ecofriendly and offers the advantage of a cost effective way of nutrient removal and biomass production [8]. Since microalgae have the ability to reduce nitrogen and phosphorus levels in wastewater [9], instead of the nutrients being wasted; this will provide nutrients for the microalgae to grow which in turn become valuable biomass products. Since microalgae has been recognized as a very favourable source of biomass, this can be applied in order to treat wastewater efficiently without involve high production cost.

The idea of using microalgae as a source of finding an alternative fish feed replacement is not something new and it is being considered important as unconventional feed ingredients in replacement of high cost feed stuffs that has been increasing [10,11]. Microalgae has the promising substitution protein-rich and lipid sources for fish, where several of studies had investigate the effect of partial replacement of fish feed with microalgae Scenedesmus sp. $[12,13]$. The objective of this study was to determine the protein and lipid content of Scenedesmus sp. cultivated in different concentration of wet market wastewater under outdoor culture condition. In addition, the morphological of Scenedesmus sp. after growing in wet market wastewater also characterised using Scanning Electron micrograph (SEM) accordingly.

\section{Materials and methods}

\subsection{Cultivations of Scenedesmus sp. using wet market wastewater}

Microalgae Scenedesmus sp. was obtained from the culture collection of Faculty of Science, Technology and Human Development, Tun Hussein Onn University of Malaysia. The inoculum of Scenedesmus sp. was maintained in Bold basal medium (BBM) prior to experiment. The experiment was set up using $2 \mathrm{~L}$ of Erlenmeyer flask containing 1.5 L of wastewater and Bold Basal Media (BBM). BBM medium was used as control media. Wastewater was transported to the laboratory and stirred for about 30 minutes and allowed to settle for 1 hour. The supernatant was separated from the remaining suspended solids and diluted with distilled water into four concentrations $(10 \%, 15 \%, 20 \%$ and $25 \%)$. Microalgae was cultivated under outdoor sunlight with continuous aeration at $3.2 \mathrm{~L} / \mathrm{min}$ to ensure the distribution of nutrients using atmospheric air from an aquarium pump through air sparger. The experiment flask was inoculated with the same initial microalgae cells of $\left(10^{6}\right.$ cells $\left./ \mathrm{ml}\right)$ at the initial day of the experiment. The biomass was harvested immediately after 12 th days by centrifugation at $4000 \mathrm{rpm}$ for $5 \mathrm{~min}$. The cultivation batches were carried out in duplicate.

\subsection{Analysis of proximate composition}

The measurement of protein, ash, fiber and moisture content was performed based on AOAC (2002) [14] methods. Lipid content was determined according to Bligh and Dyer [15] and Folch et al. [16]. All biomass samples were kept in an airtight container and were sent for further analysis of Scanning Electron Microscopy (SEM) for cell morphology characterization after cultivation. 


\section{Results and discussion}

\subsection{Protein and Lipid Content of Scenedesmus sp.}

Table 1 shows the chemical composition of Scenedesmus sp. biomass which were cultivated in different types of media. The highest protein content was recorded by $10 \% \mathrm{WM}$ followed by $15 \% \mathrm{WM}, 20 \% \mathrm{WM}, 25 \% \mathrm{WM}$ and BBM respectively. Low protein content recorded in $25 \% \mathrm{WM}$ with $37.3 \%$ while the highest protein content was recorded at $10 \% \mathrm{WM}$ with $50.72 \%$. It is to be found that the protein content increased along with the decreasing wet market wastewater ratio added to the cultures. On the other hand, the highest lipid content was found to be in $25 \% \mathrm{WM}$ with a total value of $26.7 \%$ were significantly higher than those obtained from other concentration and BBM. As the concentration goes lower, the lipid content were decreased (Fig. 1). These results show that it may possibly due to micronutrient deficiency or some other stress factor was involved; higher nitrogen involvement achieved higher lipid productivity [17].

Table 1. Proximate composition (\% of dry matter)

\begin{tabular}{|l|c|c|c|c|c|}
\hline Composition & $\mathbf{1 0} \% \mathbf{W M}$ & $\mathbf{1 5} \% \mathbf{W M}$ & $\mathbf{2 0} \% \mathbf{W M}$ & $\mathbf{2 5 \%} \mathbf{W M}$ & $\mathbf{B B M}$ \\
\hline Crude potein (\%) & $50.72 \pm 0.64$ & $41.2 \pm 0.23$ & $38.6 \pm 1.27$ & $37.3 \pm 0.10$ & $35.0 \pm 1.52$ \\
\hline Crude lipid & $8.0 \pm 0.10$ & $14.7 \pm 0.17$ & $19.9 \pm 0.18$ & $26.7 \pm 0.56$ & $15.1 \pm 0.19$ \\
\hline Ash (\%) & $3.1 \pm 0.25$ & $7.1 \pm 0.04$ & $9.2 \pm 0.67$ & $12.0 \pm 0.48$ & $10.2 \pm 0.29$ \\
\hline Moisture (\%) & $6.4 \pm 0.26$ & $8.5 \pm 0.25$ & $8.7 \pm 0.13$ & $9.0 \pm 0.10$ & $7.7 \pm 0.29$ \\
\hline Crude fiber (\%) & $6.91 \pm 0.21$ & $6.39 \pm 0.19$ & $6.72 \pm 0.36$ & $6.24 \pm 0.34$ & $6.50 \pm 0.07$ \\
\hline
\end{tabular}

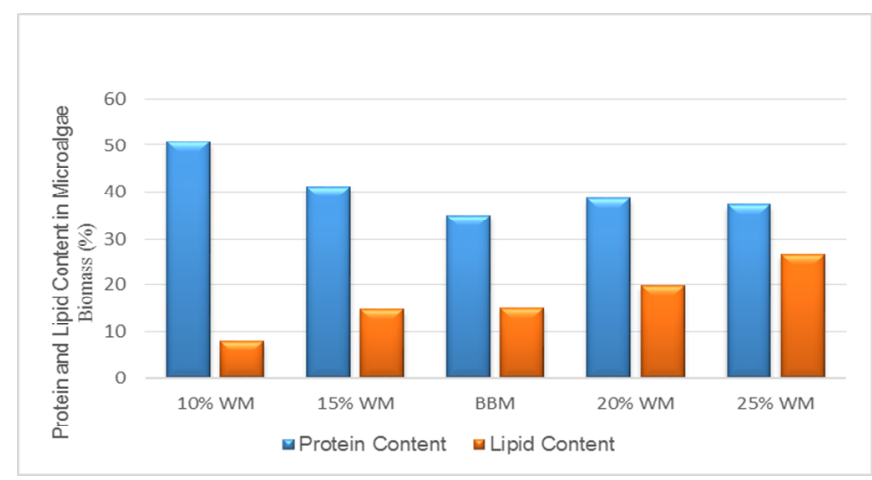

Fig. 1. Protein and lipid content

Protein content was found higher and the lipid content was lower in the $10 \% \mathrm{WM}$ than in the $25 \% \mathrm{WM}$. This measurement indicates that stress conditions in $10 \% \mathrm{WM}$ were higher than in the $25 \% \mathrm{WM}$ in the cultures. The stress condition triggered due to the nutrient content of nitrogen and phosphorus as both a particular key for protein and lipid accumulation in microalgae cells. It is likely known that the aspects of this stress conditions are tightly linked to the available amount of nutrients; limitation of nitrogen, phosphorus, and the presence of other microorganisms [18]. Moreover, the trend value of protein and lipid were similar to the values reported by Markou et al. [19] who cultivated microalgae using slaughterhouse wastewater and revealed that this phenomenon could be explained to 
the fact that the presence of higher nitrate and phosphorus concentration related to the changes in the protein and lipid content. Assuming further used for this microalgae Scenedesmus sp, as fish feed, this study is already fulfill the requirement of protein $(40 \%$ $50 \%$ ) and lipid (6\%-13\%) percentage needed for fish in the standard from Food and Agriculture Organization of The United Nations (FAO) [20]. Thus, this proximate quality of microalgae Scenedesmus sp. biomass cultivated from wet market wastewater in this study can be the ideal amount to supply in terms of protein and lipid based on the percentage amount to be consumed by fish. However, in order to simplify whether this microalgae Scenedesmus sp. biomass grown on wet market wastewater is harmless to be used as fish feed, thoroughly follow-up research is needed.

\subsection{Microalgae cell characterization via SEM}

The cell morphology of Scenesdesmus sp. that has been grown on five different of wet market wastewater media was obeserved under Scanning electron micrograph (SEM) asdepicted in Fig. 2. The SEM at the magnification of $1200 \times$ was used to characterize the biomass for both culture media (WM and BBM). It shows that wet microalgae Scenedesmus sp. biomass from each media was characterized by having different length and longer axis for all sample which ranged of $6 \mathrm{~m} \mu-8 \mu \mathrm{m}$ to $2 \mu \mathrm{m}-3 \mu \mathrm{m}$. In fact, the individual microalgae cells were found to be in spherical and unicellular as typical colonies consisting of numerous cells.
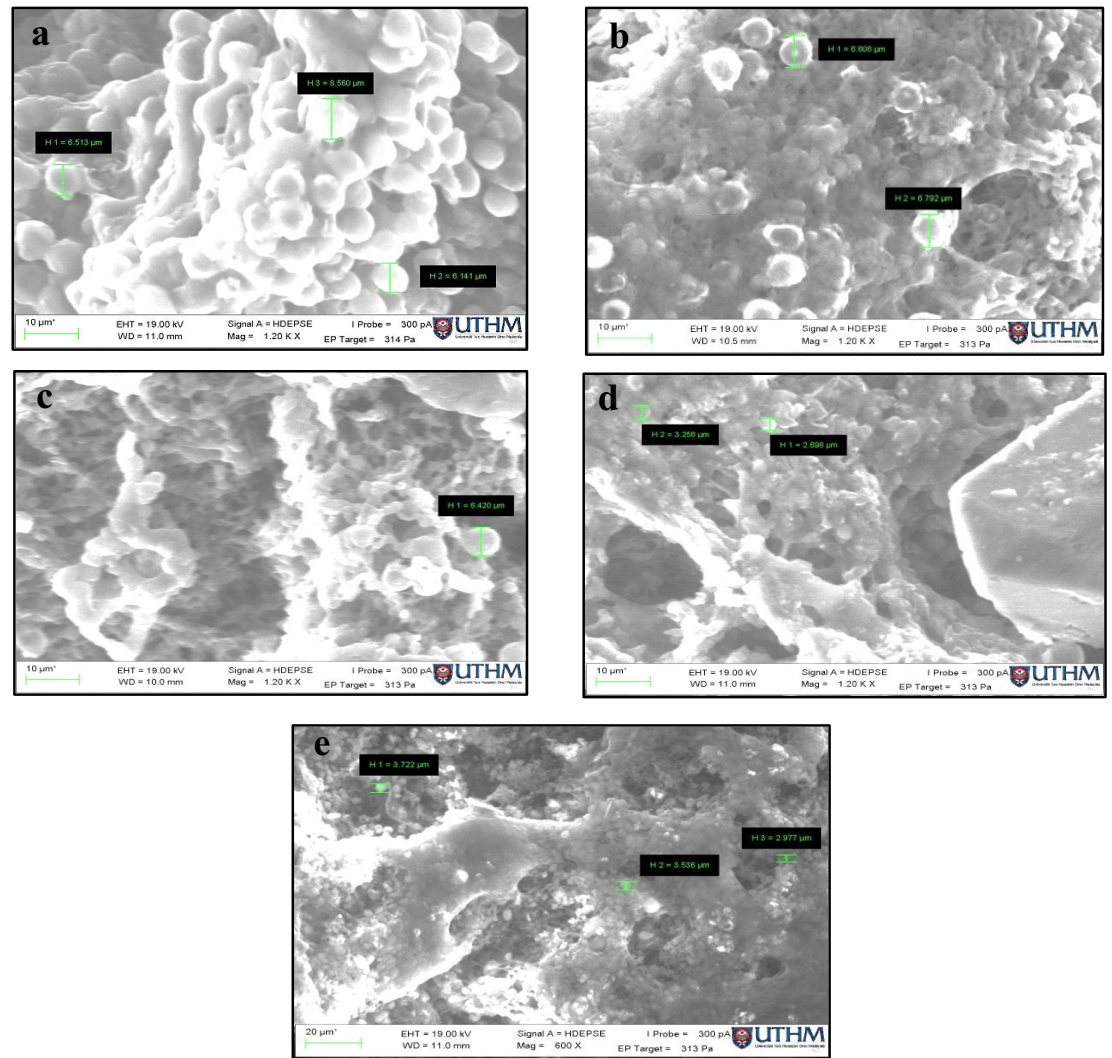

Fig. 2. SEM micrograph of 1200x (a) $10 \% \mathrm{WM} ; 6 \mathrm{~m} \mu-8 \mu \mathrm{m}$ (b) $15 \% \mathrm{WM} ; 6 \mu \mathrm{m}$ (c) $20 \mathrm{WM} ; 6 \mu \mathrm{m}$ (d) $25 \% \mathrm{WM} ; 2 \mu \mathrm{m}-3 \mu \mathrm{m}$ (e) BBM; $2 \mu \mathrm{m}-3 \mu \mathrm{m}$ 


\section{Conclusion}

This study shows that wet market wastewater can be used as an alternative media for the cultivation of microalgae Scenedesmus sp. protein and lipid content production. Among the four different concentrations of WM, 20\% WM showed the best performance in respect of protein and lipid content. Besides, a tremendously high of protein content was found in $10 \% \mathrm{WM}$ with $50.72 \%$ while high lipid content was found in $25 \% \mathrm{WM}$ with $26.7 \%$. This indicates that microalgae Scenedesmus sp. biomass was rich in protein but lower in lipid straightly can be a potential application for bio-based product such as fish feedstock. This research is also motivated by the increasing interest in application of microalgae biomass and the implementation of environmentally friendly tools in treating wastewater.

This research was funded under the PRGS (G004) and eScience Fund project no: 02-01-13-SF0135. Special thanks to Dr. Hazel Monica Matias-Peralta for providing the microalgae seed and any parties that involved in this project specifically University Tun Hussein Onn Malaysia for providing the equipment and research facilities to carry out this project. This paper was partly sponsored by the Centre for Graduate Studies UTHM.

\section{References}

[1] E.W. Becker, Micro-Algae as a Source of Protein, Biotechnology Advances, 25(2), 207-10, (2007)

[2] V. Makareviciene, A. Vaida, S. Virginija, and K. Jurate, Cultivation of Microalgae Chlorella Sp. and Scenedesmus Sp. as a Potentional, Biofuel Feedstock 57(3), 21-27, (2011)

[3] Spolaore, Pauline, Claire Joannis-Cassan, Elie Duran, and Arsene Isambert, Commercial Applications of Microalgae. Journal of bioscience and bioengineering 101(2), 87-96, (2006)

[4] I. Rawat, K. Ranjith, R. T. Mutanda, and F. Bux, Dual role of microalgae: Phycoremediation of domestic wastewater and biomass production for sustainable biofuels production, Applied Energy, 88(10), 3411-3424, (2011)

[5] A.C. Wilkie and W.W. Mulbry, Recovery of dairy nutrients by benthic freshwater algae, Bioresource Technology, 84, 81-91, (2002)

[6] H. S. Plumber and B. H. Kiepper, Impact of Poultry Processing By-Products on Wastewater Generation, Treatment and Discharges, Proc. of the 2011 Georgia Water Resources Conf., Univ. of Georgia , Athens, (2011)

[7] A. Izzuddin and Ghani, Application of bioparticle and constructed wetlands in treating wet market wastewater, Universiti Teknologi Malaysia, Undergraduate's Thesis, (2011)

[8] S. Sriram, and R. Seenivasan, Microalgae Cultivation in Wastewater for Nutrient Removal, J. of Algal Biomass Utilization 3(2), 9-13, (2012)

[9] M. Adamsson, Potential Use of Human Urine by Greenhouse Culturing of Microalgae (Scenedesmus Acuminatus), Zooplankton (Daphnia Magna) and Tomatoes (Lycopersicon). 16, 243-54, (2000)

[10]D. Van Thang, A. Faruq, S. R. Thomass-Hall, Q. Simon, N. Ekaterina and P. M. Schenk, High Protein- and High Lipid-Producing Microalgae from Northern Australia as Potential Feedstock for Animal Feed and Biodiesel, Frontiers in Bioengineering and Biotechnology, 3, (2015)

[11] Tongsiri, Sudaporn, Kringsak Mang-amphan and Yuwadee Peerapornpisal, Effect of Replacing Fishmeal with Spirulina on Growth, Carcass Composition and Pigment of 
the Mekong Giant Catfish, Asian Journal of Agricultural Sciences, 2(3), 106-110, (2010)

[12] M. B. Tartiel, E. M. Ibrahim, and M.M. Zeinhom, Partial Replacement of Fish Meal With Dried Microalga (Chlorella Spp and Scenedesmus Spp) in Nile Tilapia (Oreochromis Niloticus) Diets, Int. Symposium on Tilapia in Aquaculture, (2008)

[13]Dawah, Aida M, Efficency of Inoculating the Green Algae, 11(3), 115-25, (2007)

[14]A.O.A.C. Association of Official Analytical Chemists: Official Methods of Analysis, 18th Edition, Maryland, USA., (2005)

[15]E.G. Bligh, W.J. Dyer, $A$ rapid method of lipid extraction and purification. Canadian J. of Biochemistry and Physiology, 37, 911-917, (1959)

[16]A. L.-S, Folch, A simple method for isolation and purification of total lipids from animal tissues, J. Biol. Chem., 226, 497-509, (1957)

[17]K. Chiu-Mei, C. Tsai-Yu, L. Tsung-Hsien, K. Chien-Ya, L. Jinn-Tsyy, C. Jo-Shu and L. Chih-Sheng, Cultivation of Chlorella sp. GD using piggery wastewater for biomass and lipid production, Bioresour. Techol., 194, 326-33, (2015)

[18]Juneja, Ankita, Ruben Michael Ceballos, and Ganti S. Murthy, Effects of Environmental Factors and Nutrient Availability on the Biochemical Composition of Algae for Biofuels Production: A Review, Energies, 6(9), 4607-38, (2013)

[19] Markou, Giorgos, Dimitris Iconomou, and Koenraad Muylaert, Applying Raw Poultry Litter Leachate for the Cultivation of Arthrospira Platensis and Chlorella Vulgaris. Algal Research, 13, 79-84, (2016)

[20]Food and Agriculture Organization of the United Nations (FAO), (2013), Aquaculture Feed and Fertilizer Resources Information System, Retrieved on September 9, 2016 from http://www.fao.org/fishery/affris/species-profiles/nile-tilapia/faqs/en 